Jurnal Penelitian dan Evaluasi Pendidikan

\title{
FAKTOR DETERMINAN PRODUKTIVITAS SEKOLAH
}

\author{
Partono Thomas \\ Pendidikan Ekonomi FE UNNES \\ Kampus Sekaran Gunungpati, Semarang, 50229 \\ thomaspartono@yahoo.co.id
}

\begin{abstract}
Abstrak
Penelitian ini bertujuan untuk mengetahui faktor-faktor yang mempengaruhi produktivitas sekolah SMKN bisnis manajemen. Penelitian ini menggunakan pendekatan kuantitatif. Ukuran sampel sebanyak 200, dipilih dengan teknik proportional random sampling. Data dikumpulkan dengan metode angket wawancara dan dokumentasi. Analisis data dengan permodelan persamaan struktural (structural equation modeling, SEM). Hasil penelitian me-nunjukkan bahwa produktivitas sekolah untuk SMKN bisnis manajemen dipengaruhi oleh mutu proses, kompetensi guru, budaya organisasi sekolah, pembiayaan pendidikan, kepemimpinan kepala sekolah dan peran komite sekolah. Pengaruh variabel bebas terhadap produktivitas sekolah sebesar $73 \%$ sisanya $27 \%$ di-pengaruhi faktor lain di luar model. Variabel dominan yang mem-pengaruhi produktivitas SMKN bisnis manajemen adalah mutu proses.
\end{abstract}

Kata kunci: produktivitas SMK business-management, mutu proses, kompetensi guru, budaya organisasi sekolah, pembiayaan, kepemimpinan, komite sekolah 
Jurnal Penelitian dan Evaluasi Pendidikan

\title{
THE DETERMINANT FACTORS OF SCHOOLS'S PRODUCTIVITY
}

\author{
Partono Thomas \\ Pendidikan Ekonomi FE UNNES \\ Kampus Sekaran Gunungpati, Semarang, 50229 \\ thomaspartono@yahoo.co.id
}

\begin{abstract}
The purpose of this study is to identify the factors that affect school productivity in SMKN of Business and Management. The sample consisted of 200 teachers selected using proportional random sampling technique. Questionnaire, interviews and documentation methods are used for collecting data. For analyzing the data, the research used structural equation modeling (SEM). Findings of this research show that School Productivity in SMKN of business-management field is influenced by the process quality, teachers' competencies, school organizational culture, education financial, leadership and the role of the school committee. Impact of independent variables on the school productivity was $73 \%$, while $27 \%$ or the rest is influenced by other factors. The dominance variable that influences the productivity is the quality process.
\end{abstract}

Keywords: productivity in SMK of business-management, quality processes, competence of teachers, organizational culture of schools, financing, leadership and school committees 


\section{Pendahuluan}

Menurut Tilaar (2003:150) dunia pendidikan Indonesia mengalami empat krisis pokok yaitu kualitas, relevansi atau efisiensi eksternal, elitisme dan manajemen. Secara khusus efisiensi eksternal SMK masih menjadi masalah, berkaitan dengan jumlah pengangguran lulusan SMK di Indonesia cukup besar. Menurut BPS di Jakarta, tingkat pengangguran SMK di Indonesia bulan Januari 2009 sebesar 17,26\%. Angka putus sekolah tahun 2009/2010 di kota Surakarta terjadi di semua jenjang. Angka putus sekolah pada jenjang SMA/MA/SMK sebesar 115 anak. Adanya angka putus sekolah di sekolah SMK menunjukkan efisiensi internal belum optimal.

Terkait dengan permasalahan tersebut, maka penelitian dengan tema produktivitas SMK bisnis manajemen perlu dilakukan yang mencakup keefektifan, efisiensi internal, efisiensi eksternal dan mutu lulusan. Keefektifan tampak pada pencapaian target lulusan secara kuantitatif maupun secara kualitatif. Efisiensi internal tampak pada, rendahnya angka tinggal kelas, rendahnya angka putus sekolah dan banyaknya siswa berprestasi. Efisiensi eksternal tampak pada banyaknya siswa diterima melanjutkan studi dan banyaknya lulusan diterima di dunia kerja. Mutu lulusan adanya kesesuaian lulusan dengan apa yang dibutuhkan masyarakat dan dunia kerja.

Produktivitas adalah kemampuan untuk menghasilkan sesuatu, jika dikaitkan dengan kinerja maka mengarah pada efektivitas dan efisiensi, selaras dengan pendapat Robbins (2007:29) produktivitas ukuran kinerja mencakup sasaran (efektivitas) dan efisiensi. Untuk efisiensi pendidikan dibedakan antara efesiensi internal dan efisiensi eksternal (Taruno:2008). Menurut Thomas (1971:12-13) produktivitas sekolah mencakup tiga fungsi, yaitu keluaran administratif, keluaran perilaku dan keluaran ekonomi/ peningkatan nilai tambah. Keluaran administrasi ditunjukkan seberapa baik layanan yang dapat diberikan guru, kepala sekolah, karyawan dalam proses pendidikan. Keluaran perilaku ditunjukkan, dengan prestasi akademik dan prestasi nonakademik. Keluaran ekonomi dan peningkatan nilai tambah ditunjukkan dengan perolehan siswa setelah selesainya program.

Penelitian dengan tema produktivitas sekolah telah dilakukan oleh Firdaus (2005), Mulyani (2007) dan Utomo (2007), semua dilakukan di 
sekolah lanjutan umum, dan masih berkisar mempermasalahkan jumlah lulusan hasil Ujian Nasional. Padahal menurut pengertian tersebut harus mencakup keefektifan, efisiensi internal, efisiensi eksternal dan mutu lulusan.

Produktivitas SMK bisnis manajemen memiliki nuansa yang berbeda dengan produktivitas sekolah lanjutan umum (SMU), karena pada SMK bisnis manajemen selain melanjutkan studi, lulusannya dipersiapkan masuk dunia kerja. Dunia industri membutuhkan tenaga kerja yang memiliki kejujuran, tekun, ramah, disiplin dan kompeten di bidangnya.

Studi produktivitas SMK bisnis manajemen bertujuan membantu memecahkan masalah pendidikan di Indonesia dalam kaitannya dengan efisiensi internal dan efisiensi eksternal. Sudah saatnya penyelenggara pendidikan SMK bisnis manajemen tidak hanya merencanakan jumlah lulusan tetapi juga memikirkan apakah lulusannya nanti dapat studi lanjut dan diterima di dunia kerja. Penelitian ini berbeda dengan penelitian masalah produktivitas dari penelitian yang sudah dilakukan karena mengacu pada produktivitas sekolah yang diterapkan pada produktivitas total dan dikenal sebagai fungsi produksi dari Cobb Douglas. Cobb Douglas menyatakan bahwa produksi dipengaruhi oleh faktor modal dan tenaga kerja (Doll, 1984:21; Mathias, 1986:61). Ada pula faktor lain yang diduga mempengaruhi produktivitas sekolah seperti mutu proses, kompetensi guru, budaya organisasi sekolah, pembiayaan pendidikan, kepemimpinan kepala sekolah dan peran komite sekolah.

Menurut Encyclopedia of Management (2006:703), faktor yang mempengaruhi produktivitas adalah

Capital investments in production, capital investments in technology, capital investments in equipment, capital investments in facilities, economies of scale, workforce knowledge and skill resulting from training and experience, technological changes, work methods, procedures, systems, quality of products, quality of processes, quality of management, legislative and regulatory environment, general levels of education, social environment, geographic factors. 
Menurut Prosser (2010), sekolah kejuruan akan berhasil jika disediakan lingkungan belajar yang sesuai dengan lingkungan di tempat kelak mereka akan bekerja, latihan kejuruan efektif jika tugas-tugas yang diberikan di dalam latihan memiliki kesamaan operasional dengan yang akan dipergunakan di dalam kerjanya kelak, dibiasakan dengan perilaku yang akan diperagakan dalam pekerjaannya, pemberian latihan berulang-ulang sehingga diperoleh penguasaan yang tepat, pelatihnya cukup berpengalaman dan menerapkan kemampuan dan minimal yang harus dimiliki oleh individu.

Produktivitas SMK bisnis manajemen mengikutsertakan pendayagunaan secara terpadu sumber daya manusia (guru, kepala sekolah, tenaga kependidikan), keterampilan, barang modal (gedung, mesin kantor, komputer), teknologi, kurikulum, manajemen, dan informasi. SMK bisnis manajemen dikatakan produktif jika tujuan dan target yang dicanangkan sekolah tercapai dengan biaya terendah. Tujuan setiap sekolah biasanya tertulis sebagai visi, misi dan target dalam rencana strategis sekolah. Tujuan SMK bisnis manajemen bukan semata-mata jumah lulusan, tetapi apakah lulusannya nanti cocok jika bekerja, memuaskan pelanggan internal (guru, siswa, tenaga administrasi) dan pelanggan eksternal (dunia industri/dunia kerja). Dengan memasukkan beberapa input yang diduga mempengaruhi produktivitas sekolah seperti mutu proses, kompetensi guru, budaya organisasi sekolah, pembiayaan pendidikan, kepemimpinan kepala sekolah dan peran komite sekolah. Terkait dengan permasalahan tersebut, penelitian ini bertujuan untuk mengetahui faktor-faktor yang mempengaruhi produktivitas sekolah untuk SMK bisnis manajemen.

\section{Metode Penelitian}

Penelitian ini termasuk penelitian deskriptif eksploratif. Populasi penelitian adalah semua guru SMK Negeri Bisnis di Eks-Keresidenan Surakarta, sejumlah 666 orang. Sampel berjumlah 200 orang, diambil dengan proportional random sampling. Jumlah sampel masing-masing sekolah diambil secara proporsi-onal, sedangkan pemilihan individu anggota sampel dengan undian. Jumlah sampel 200 orang cukup efektif dalam 
analisis SEM (Ghozali, 2005:13). Pengambilan sampel juga mempertimbangkan tingkat kesalahan 10\%.

Variabel laten endogen terdiri dari dua yaitu mutu proses (y1) dan produktivitas sekolah (ฤ2). Variabel laten eksogen ada lima, yaitu kompe-

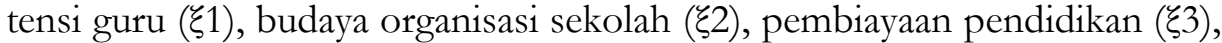

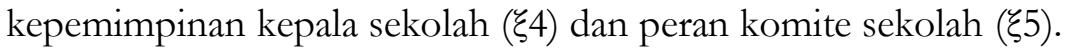

Reliabilitas instrumen diestimasi menggunakan formula Cronbach's Alpha, yakni matriks interkorelasi antarskor item atau butir instrumen. Menurut Ghozali (2007:42) suatu konstruk atau variabel dikatakan reliabel jika masing-masing variabel memiliki Cronbach's Alpha lebih besar dari 0,60.

Konseptualisasi model penelitian, digambarkan dalam bentuk diagram jalur yang disajikan pada Gambar 1.

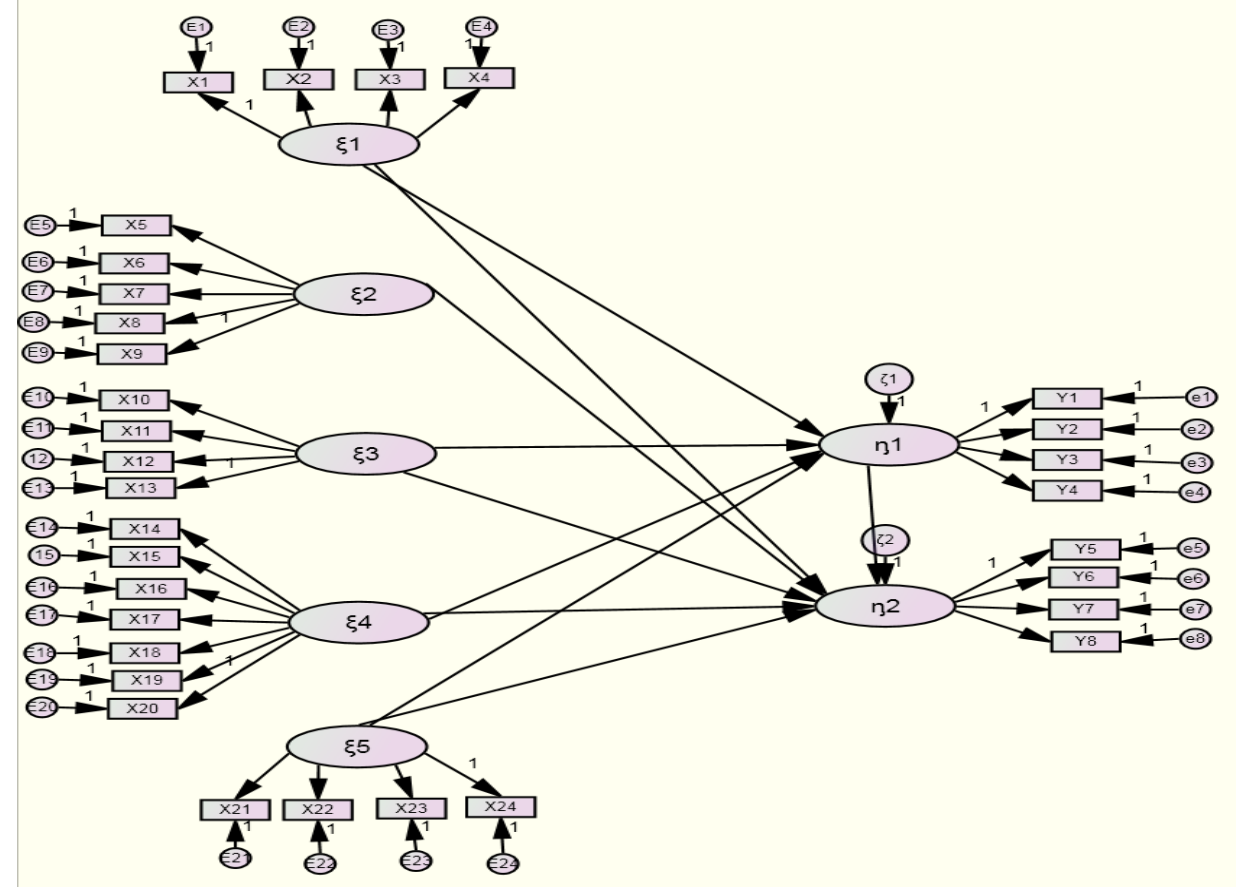

Gambar 1. Diagram Jalur Model Hubungan Antarvariabel 
Metode pengumpulan data yang utama adalah metode kuesioner, selanjutnya untuk mengecek kebenaran, melengkapi data dari metode tersebut digunakan metode dokumentasi, dan wawancara. Teknik statistik untuk menganalisis variabel pengamatan/indikator, variabel laten, dan kekeliruan pengukuran secara sekaligus adalah Model Persamaan Struktural (Structural Equation Modelling, SEM). Dengan SEM dapat dianalisis bagaimana hubungan antarvariabel indikator dengan variabel latennya, yang dikenal dengan persamaan pengukuran (measurement equation), hubungan antara variabel laten yang satu dengan laten lainnya dikenal dengan persamaan struktural (structural equation) yang secara bersama-sama melibatkan kekeliruan pengukuran. Dalam SEM dikenal variabel laten eksogen dan variabel laten endogen (Ghozali \& Fuad, 2005:11).

\section{Hasil Penelitian dan Pembahasan}

Ringkasan hasil estimasi koefisien jalur dan kesalahan (error) dengan SEM disajikan pada Tabel 1. Hasil tersebut menunjukkan bahwa model pengukuran memiliki fit baik. Setiap indikator memiliki skor t lebih besar dari 1,96 untuk taraf signifikansi 5\%. Oleh karena itu, nilai estimasi koefisien jalur (loading) dapat digunakan sebagai koefisien validitas.

Tabel 1. Ringkasan Hasil Perhitungan Indikator

\begin{tabular}{clcccccc}
\hline Indikator & Indikator Variabel & $\begin{array}{c}\text { Nilai } \\
\text { Loading }\end{array}$ & Nilai t & t tabel & $\begin{array}{c}\text { Error } \\
\text { Varians }\end{array}$ & $\mathrm{r}$ & $\mathrm{R}^{2}$ \\
\hline $\mathrm{X}_{1}$ & Kompetensi Pedagogik & 0,50 & 11,43 & 1,96 & 2,21 & 0,74 & 0,55 \\
$\mathrm{X}_{2}$ & Kompetensi Kepribadian & 0,62 & 13,75 & 1,96 & 1,14 & 0,85 & 0,73 \\
$\mathrm{X}_{3}$ & Kompetensi Sosial & 0,49 & 9,09 & 1,96 & 0,39 & 0,62 & 0,38 \\
$\mathrm{X}_{4}$ & Kompetensi Profesional & 0,25 & 9,82 & 1,96 & 0,31 & 0,66 & 0,43 \\
$\mathrm{X}_{5}$ & Inovasi & 0,42 & 10,55 & 1,96 & 2,15 & 0,73 & 0,54 \\
$\mathrm{X}_{6}$ & Perhatian terhadap detail & 0,56 & 12,68 & 1,96 & 1,19 & 0,79 & 0,62 \\
$\mathrm{X}_{7}$ & Orientasi pada manusia & 0,41 & 10,53 & 1,96 & 0,19 & 0,69 & 0,47 \\
$\mathrm{X}_{8}$ & Orientasi pada team & 0,47 & 9,20 & 1,96 & 2,36 & 0,62 & 0,38 \\
$\mathrm{X}_{9}$ & Agresivitas & 0,40 & 9,59 & 1,96 & 1,24 & 0,64 & 0,41 \\
$\mathrm{X}_{10}$ & Variasi Sumber & 0,47 & 8,44 & 1,96 & 1,33 & 0,57 & 0,33 \\
$\mathrm{X}_{11}$ & Alokasi dana & 0,27 & 11,49 & 1,96 & 2,44 & 0,73 & 0,54 \\
$\mathrm{X}_{12}$ & Kecukupan Dana & 0,41 & 10,37 & 1,96 & 1,20 & 0,68 & 0,46 \\
\hline
\end{tabular}


Jurnal Penelitian dan Evaluasi Pendidikan

\begin{tabular}{|c|c|c|c|c|c|c|c|}
\hline Indikator & Indikator Variabel & $\begin{array}{c}\text { Nilai } \\
\text { Loading }\end{array}$ & Nilai t & $\mathrm{t}$ tabel & $\begin{array}{c}\text { Error } \\
\text { Varians }\end{array}$ & $\mathrm{r}$ & $\mathrm{R}^{2}$ \\
\hline $\mathrm{X}_{13}$ & PrinsipPengelolaan Dana & 0,32 & 12,47 & 1,96 & 2,11 & 0,78 & 0,61 \\
\hline $\mathrm{X}_{14}$ & Edukator & 0,41 & 11,65 & 1,96 & 0,15 & 0,73 & 0,53 \\
\hline $\mathrm{X}_{15}$ & Manager & 0,45 & 10,60 & 1,96 & 1,17 & 0,73 & 0,53 \\
\hline $\mathrm{X}_{16}$ & Administator & 0,40 & 11,46 & 1,96 & 2,14 & 0,72 & 0,52 \\
\hline $\mathrm{X}_{17}$ & Supervisor & 0,48 & 10,01 & 1,96 & 1,32 & 0,65 & 0,42 \\
\hline $\mathrm{X}_{18}$ & Leader & 0,44 & 10,39 & 1,96 & 2,24 & 0,67 & 0,45 \\
\hline $\mathrm{X}_{19}$ & Wirausaha & 0,32 & 9,67 & 1,96 & 1,14 & 0,70 & 0,49 \\
\hline $\mathrm{X}_{20}$ & Climate Maker & 0,61 & 9,31 & 1,96 & 1,23 & 0,66 & 0,43 \\
\hline $\mathrm{X}_{21}$ & Badan Pertimbangan & 0,32 & 11,22 & 1,96 & 2,14 & 0,76 & 0,58 \\
\hline $\mathrm{X}_{22}$ & Badan Pendukung & 0,35 & 10,41 & 1,96 & 2,12 & 0,71 & 0,51 \\
\hline $\mathrm{X}_{23}$ & Badan Pengontrol & 0,42 & 9,49 & 1,96 & 1,13 & 0,66 & 0,44 \\
\hline $\mathrm{X}_{24}$ & Badan Penghubung & 0,57 & 5,25 & 1,96 & 2,35 & 0,44 & 0,19 \\
\hline $\mathrm{Y}_{1}$ & Mutu data Informasi & 0,36 & 7,49 & 1,96 & 2,11 & 0,87 & 0,75 \\
\hline $\mathrm{Y}_{2}$ & Mutu Pembelajaran & 0,25 & 9,58 & 1,96 & 1,30 & 0,64 & 0,41 \\
\hline $\mathrm{Y}_{3}$ & Mutu Kurikulum & 0,39 & 12,92 & 1,96 & 1,13 & 0,80 & 0,64 \\
\hline $\mathrm{Y}_{4}$ & Mutu Sumber Daya & 0,44 & 6,94 & 1,96 & 2,62 & 0,49 & 0,24 \\
\hline $\mathrm{Y}_{5}$ & Efektivitas & 0,52 & 8,26 & 1,96 & 4,03 & 0,94 & 0,89 \\
\hline $\mathrm{Y}_{6}$ & Efisiensi Internal & 0,46 & 11,15 & 1,96 & 1,11 & 0,81 & 0,66 \\
\hline $\mathrm{Y}_{7}$ & Efisiensi Eksternal & 0,58 & 6,42 & 1,96 & 2,66 & 0,42 & 0,18 \\
\hline $\mathrm{Y}_{8}$ & Mutu lulusan & 0,32 & 9,46 & 1,96 & 1,18 & 0,59 & 0,35 \\
\hline
\end{tabular}

Sumber: Pengolahan data dengan Lisrel

Uji Model secara Keseluruhan

Gambar 2 tersebut merupakan gambar hasil analisis SEM dengan Lisrel. Ho yang menyatakan kecocokan model tidak ditolak jika p-value lebih besar dari 0,05 dan RMSEA lebih kecil dari 0,05. Berdasarkan perhitungan diperoleh p-value 0,11381>0,05 dan RMSEA 0,017<0,05. Ini berarti dapat disimpulkan Ho tidak ditolak yang berarti model yang diuji merupakan model yang sesuai sehingga produktivitas SMK bisnis manajemen dipengaruhi mutu proses, kompetensi guru, budaya organisasi sekolah, pembiayaan, kepemimpinan kepala sekolah dan peran komite sekolah.

Secara rinci besarnya pengaruh langsung, pengaruh tidak langsung dan pengaruh total variabel independen terhadap produktivitas sekolah disajikan pada Tabel 2 . 


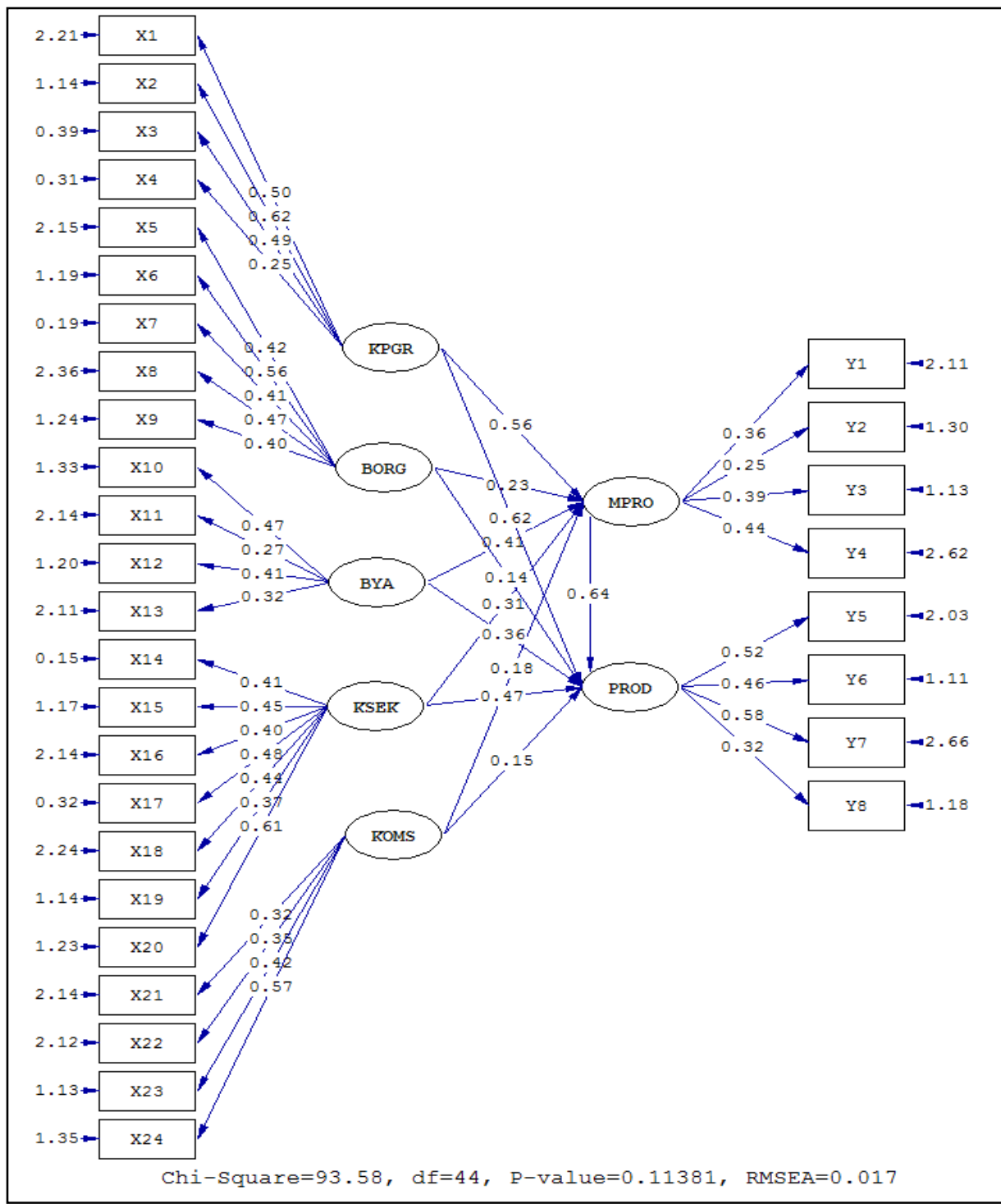

Gambar 2. Uji Model secara Keseluruhan

Faktor-Faktor yang Mempengarubi Produktivitas SMKN - 63 
Tabel 2. Pengaruh Total Variabel terhadap Produktivitas Sekolah

\begin{tabular}{lllccc}
\hline No & \multicolumn{1}{c}{ Variabel } & $\begin{array}{c}\text { Pengaruh } \\
\text { Langsung } \\
(\mathrm{LS})\end{array}$ & $\begin{array}{c}\text { Pengaruh } \\
\text { Tidak Langsung } \\
(\mathrm{TL})\end{array}$ & $\begin{array}{c}\text { Pengaruh } \\
\text { Total }\end{array}$ & Ket. \\
\hline 1. & Kompetensi guru & 0,62 & 0,358 & 0,978 & LS>TL \\
2. & Budaya Organisasi sekolah & 0,14 & 0,147 & 0,287 & LS $<$ TL \\
3. & Pemb.Pendidikan & 0,36 & 0,262 & 0,622 & LS > TL \\
4. & Kepemimpinan Kepsek & 0,47 & 0,198 & 0,668 & LS>TL \\
5. & Komite Sekolah & 0,15 & 0,115 & 0,265 & LS>TL \\
6. & Mutu Proses & 0,64 & - & - & LS \\
\hline $\mathrm{R}^{2}=0,73$ & & & &
\end{tabular}

Kontribusi Kompetensi Guru terhadap Mutu Proses dan Produktivitas Sekolah

Kontribusi variabel kompetensi guru terhadap mutu proses sebesar 0,56 dengan arah positif, artinya semakin baik kompetensi guru semakin baik pula mutu proses. Kontribusi variabel kompetensi guru terhadap produktivitas sekolah sebesar 0,62 dengan arah positif, artinya semakin baik kompetensi guru semakin baik pula produktivitas sekolah. Pengaruh tidak langsung variabel kompetensi guru terhadap produktivitas sekolah $=(0,56)(0,64)=0,358$. Pengaruh total variabel kompetensi guru terhadap produktivitas sekolah $0,62+0,358=0,978$ atau $97,8 \%$. Indikator yang baik validitasnya, yaitu kompetensi profesional $\left(\mathrm{X}_{4}\right)$.

Guru SMK bisnis manajemen yang menguasai bidang akademik, menguasai metodologi pengajaran, memahami karakteristik tentang peserta didik, mampu mengikuti perkembangan ilmu pengetahuan dan teknologi, mampu memotivasi anak, mempunyai bakat mendidik, sabar, penuh inisiatif akan meningkatkan mutu proses dan produktivitas sekolah. Guru merupakan komponen utama yang menjadi pelaku organisasi sekolah. Guru SMK bisnis manajemen adalah pengajar di kelas sekaligus pembimbing siswa di dunia kerja.

Menurut Hutapea (2008:64), organisasi dapat berprestasi unggul apabila orang-orang yang bekerja dalam organisasi dapat memberikan kontribusi maksimal sesuai dengan tugas dan kemampuannya. Guru yang 
selalu mengikuti perkembangan ilmu pengetahuan dan berusaha untuk meningkatkan pengetahuan dengan studi lanjut atau mengadakan penelitian akan meningkatkan mutu pembelajaran. Hal ini sesuai dengan pendapat Martono (2009), guru sebagai unsur strategis dan sebagai ujung tombak dalam merealisasikan tujuan untuk mewujudkan produktivitas sekolah yang berkualitas. Kualifikasi akademik memadai, di dalam pembelajaran menerapkan berbagai pendekatan, strategi, dan melatih kompetensi siswa di dunia industri. Temuan penelitian menunjukkan bahwa variabel kompetensi guru mempunyai pengaruh paling besar ter-hadap mutu proses dan produktivitas sekolah.

Kontribusi Budaya Organisasi Sekolah terhadap Mutu Proses dan Produktivitas Sekolah

Kontribusi variabel budaya organisasi sekolah terhadap mutu proses sebesar 0,23 dengan arah positif, artinya semakin baik budaya organisasi sekolah semakin baik pula mutu proses. Indikator yang baik validitasnya yaitu inovasi $\left(\mathrm{X}_{5}\right)$. Pengaruh langsung variabel budaya organisasi sekolah terhadap produktivitas sekolah 0,14. Pengaruh tidak langsung terhadap produktivitas sekolah $(0,23)(0,64)=0,147$. Pengaruh total variabel budaya organisasi sekolah terhadap produktivitas sekolah $=0,14+0,147=0,287$ atau $28,7 \%$.

Kecilnya pengaruh budaya organisasi sekolah terhadap produktivitas sekolah ini juga selaras temuan Ekosusilo (2003), budaya tulis ketat khususnya dalam penyusunan rencana dan program kerja kepala sekolah tidak pernah diketahui bawahan. Tidak diketahuinya program kerja oleh bawahan termasuk guru dan karyawan karena kurangnya keterbukaan kepala sekolah, hal ini akan mengurangi gairah kerja bawahan dalam mencapai tujuan dan target yang harus dicapai sekolah.

Walaupun pengaruhnya kecil, temuan ini selaras dengan temuan Mulyani, (2007:101) ada pengaruh yang signifikan budaya sekolah terhadap produktivitas sekolah. Menurut Usman (2006;172), budaya sekolah yang mendukung mutu pendidikan adalah kerjasama, sinergi untuk berbuat yang 
terbaik, memberi penghargaan kepada yang berprestasi dan meningkatkan komitmen untuk belajar.

Hal ini memberikan bukti bahwa budaya organisasi sekolah perlu dikembangkan dalam sekolah. Pengembangan budaya organisasi yang memberikan kesempatan pada anggota sekolah, akan memberikan dampak terciptanya budaya organisasi yang kuat. Budaya organisasi yang kuat, perilaku anggotanya dibatasi oleh kesepakatan bersama dan bukan karena perintah atau karena ketentuan-ketentuan formal. Penciptaan budaya organisasi di sekolah memberikan peluang pada guru, karyawan, siswa untuk berinovasi, berkreasi dan berkompetisi.

Kontribusi Pembiayaan Pendidikan terhadap Mutu Proses dan Produktivitas Sekolah

Kontribusi variabel pembiayaan pendidikan terhadap mutu proses sebesar 0,41 dengan arah positif, artinya semakin baik pembiayaan pendidikan semakin baik pula mutu proses. Kontribusi variabel pembiayaan pendidikan terhadap produktivitas sekolah sebesar 0,36 dengan arah positif, artinya semakin baik pembiayaan pendidikan semakin baik pula produktivitas sekolah. Pengaruh tidak langsung variabel pembiayaan pendidikan terhadap produktivitas sekolah $(0,41)(0,64)=0,262$. Pengaruh total variabel pembiayaan pendidikan terhadap produktivitas sekolah $=0,36$ $+0,262=0,622$ atau $62,2 \%$.

Kecukupan pembiayaan akan menggairahkan guru dalam mengajar dan menggairahkan siswa dalam belajar. Hasil penelitian juga selaras dengan penelitannya Kardoyo (2005) pembiayaan pendidikan berpengaruh terhadap mutu proses belajar mengajar di SMU kota Semarang. Pembiayaan pendidikan di SMKN bisnis manajemen termasuk dalam kategori cukup dengan sumber pendanaan utama dari orang tua dan pemerintah. Strategi pembiayaan dapat dilakukan dengan (1) penjualan produk dan jasa sekolah seperti jasa transport dan jasa pengetikan, (2) kerja sama dengan dunia kerja sebagai penyalur atas produk lewat koperasi sekolah, (3) dan penyelenggaraan kursus dengan mengoptimalkan laboratorium mengetik, akuntansi, dan komputer. 
SMK bisnis manajemen di Eks-Keresidenan Surakarta menganggarkan dana untuk siswa yang berprestasi di bidang akademik ataupun nonakademik dengan memberikan beasiswa, dana yang dialokasikan rata-rata sebesar 2,84\%. Reward yang diberikan pada siswa dapat menumbuhkan motivasi berprestasi dan meningkatkan jiwa kompetisi antarsiswa.

Hasil penelitian ini selaras dengan penelitiannya Hidayat (2003), manajemen pembiayaan pendidikan berpengaruh terhadap proses peningkatan produktivitas. Anwar (2004:122) menegaskan bahwa dalam kondisi yang ideal ketersediaan biaya yang memadai dengan manajemen pembiayaan yang lebih baik dapat menyumbangkan peningkatan hasil pendidikan baik dilihat dari jumlah maupun mutunya.

Kontribusi Kepemimpinan Kepala Sekolah terhadap Mutu Proses dan Produktivitas Sekolah

Kontribusi variabel kepemimpinan kepala sekolah terhadap mutu proses sebesar 0,31 dengan arah positif, artinya semakin baik kepemimpinan kepala sekolah semakin baik pula mutu proses. Hasil penelitian juga selaras dengan penelitannya Kardoyo (2005) yang mengatakan ada pengaruh antara kepemimpinan kepala sekolah terhadap mutu proses.

Kegiatan di laboratorium dapat berjalan dengan baik di SMK bisnis manajemen. Keberadaan komputer tidak hanya digunakan untuk efisiensi dan efektivitas dalam pengelolaan penyelenggaraan sekolah tetapi juga dapat digunakan untuk mempermudah menunjukkan pengetahuan. Mutu pembelajaran SMK bisnis manajemen di Eks-Keresidenan Surakarta cukup berkesan, menyenangkan dan positif dengan indeks kemangkiran siswa, angka tinggal kelas mengalami penurunan.

Kontribusi kepemimpinan kepala sekolah terhadap produktivitas sekolah sebesar 0,47 dengan arah positif, artinya semakin baik kepemimpinan kepala sekolah semakin baik pula produktivitas sekolah. Pengaruh tidak langsung variabel kepemimpinan kepala sekolah terhadap produktivitas sekolah sebesar $(0,31)(0,64)=0,198$. Pengaruh total variabel kepemimpinan kepala sekolah terhadap produktivitas sekolah yaitu 0,47+ $0,198=0,668$ atau $66,8 \%$. 
Kepala sekolah SMK mampu meyakinkan dan menggerakkan seluruh guru, seluruh tenaga kependidikan dan siswa sehingga semua warga sekolah dapat mengaktualisasikan ide, kreativitas, inovasi, kerja sama dan kompetensi. Kepala sekolah menjaga hubungan baik dengan siswa, orang tua, karyawan, guru, komite sekolah, sesama kepala SMK, dunia industri dan dengan masyarakat. Temuan ini selaras dengan temuan Mulyani (2007:101) yang menyatakan ada pengaruh yang signifikan kepemimpinan kepala sekolah dengan produktivitas sekolah.

Kepemimpinan kepala sekolah besar perannya dalam meningkatkan mutu proses dan produktivitas sekolah. Kepala sekolah merupakan motor penggerak, penentu kebijakan sekolah, yang menentukan bagaimana target dan tujuan sekolah dapat direalisasikan. Kepala sekolah yang efektif akan tercermin peranan yang diterapkan dan berhasil mewujudkan target, tujuan sekolah. Pencapaian target dan tujuan dijadikan alat kontrol untuk mengetahui kekuatan dan kelemahan dalam meningkatkan mutu proses dan produktivitas sekolah.

Hal ini selaras dengan pendapat Suyanto (2009) yang menyatakan dalam era desentralisasi dan otonomi kepala sekolah harus bertindak sebagai manajer dan pemimpin yang efektif. Sebagai manajer harus mampu mengatur agar semua potensi sekolah dapat berfungsi secara optimal.

Kontribusi Peran Komite Sekolah terhadap Mutu Prosesdan Produktivitas Sekolah

Kontribusi variabel peran komite sekolah terhadap mutu proses sebesar 0,18 dengan arah positif, artinya semakin baik peran komite sekolah semakin baik pula mutu proses. Kontribusi variabel peran komite sekolah terhadap produktivitas sekolah sebesar 0,15 dengan arah positif, artinya semakin baik peran komite sekolah sekolah semakin baik pula produktivitas sekolah. Pengaruh tidak langsung variabel peran komite sekolah terhadap produktivitas sekolah $(0,18)(0,64)$ sebesar 0,115 . Pengaruh total variabel peran komite sekolah terhadap Produktivitas Sekolah yaitu $0,15+0,115=0,265$ atau $26,5 \%$. 
Komite SMK bisnis manajemen di Eks-Keresidenan Surakarta, melakukan pengawasan terhadap perencanaan, kualitas program SMK bisnis manajemen, sumber daya, alokasi anggaran dan memantau partisipasi stakeholder pendidikan. Kebijakan pengembangan sekolah bukan hanya tanggung jawab kepala sekolah dan guru, tetapi orang tua/wali murid dan masyarakat. Temuan ini mendukung temuan Wiyanti (2005) yang menyatakan peranan komite sekolah berpengaruh terhadap produktivitas SMA Swasta di kota Semarang.

Peran komite sekolah di SMK bisnis manajemen di Eks-Keresidenan Surakarta, khususnya dalam mencari sumber dan penggunaan dana baik. Akan tetapi, dalam pertimbangan perencanaan input, pendukung pembelajaran dan pengontrol atas lulusan yang dihasilkan belum optimal.

Kontribusi Mutu Proses terhadap Produktivitas Sekolah

Kontribusi variabel mutu proses terhadap produktivitas sekolah sebesar 0,64 dengan arah positif, artinya semakin baik mutu proses semakin baik pula produktivitas sekolah. Koefisien regresi mutu proses mempunyai nilai tertinggi terhadap produktivitas sekolah. SMK bisnis manajemen melengkapi sarana dan prasarana sesuai dengan perkembangan zaman sehingga memungkinkan terlaksananya pembelajaran yang berbasis teknologi informasi dan komunikasi.

\section{Simpulan}

Berdasarkan hasil penelitian dan pembahasan dapat disimpulkan bahwa produktivitas di SMK bisnis manajemen di Eks-Keresidenan Surakarta dipengaruhi oleh mutu proses, kompetensi guru, budaya organisasi sekolah, pembiayaan, kepemimpinan kepala sekolah dan peran komite sekolah. Pengaruhnya sebesar $73 \%$ sisanya dipengaruhi variabel lain di luar model. Variabel dominan yang mempengaruhi produktivitas SMKN bisnis manajemen adalah mutu proses.

SMK bisnis manajemen, pemerintah dan dunia industri dapat menggunakan model dalam rangka meningkatkan produktivitas SMKN bisnis manajemen, dengan mengelola koefisien regresi variabel yang telah 
teruji dan melihat skala prioritas. Prioritas pertama, variabel mutu proses dengan pengadaan peralatan yang representatif sesuai yang digunakan di dunia kerja. Kedua, variabel kompetensi guru dengan berbagai penataran, studi lanjut sesuai bidang studi, seminar dan PTK.

\section{Daftar Pustaka}

Anwar, Moch. Idochi. (2004). Administrasi Pendidikan dan Manajemen Biaya Pendidikan. Bandung: Alfabeta.

Aroef, Mathias. (1986). Pengukuran Produktivitas Kebutuban Mendesak di Indonesia. Jakarta: Prisma Aditya Media.

Doll, John P., \& Orazem, Frank. (1984). Production Economics, Theorywith Appli-cations. New York: John Wiley \& Son.

Ekosusilo, Madyo. (2003). Supervisi Pengajaran dalam Latar Budaya Jawa Studi Kasus Pembinaan Guru SD di kraton Surakarta. Sukohardjo: UNIVET Batara Press.

Firdaus. (2005). Manajemen Pembiayaan Pendidikan dan Dampaknya terhadap Produktivitas Sekolah. (Kajian pada Madrasah Tsanawiyah Negeri di Kabupaten Cianjur). http://digilib.upi.edu/pasca/ diakses 14 November 2008.

Ghozali, Imam. (2007). Analisis Multivariat dengan Program SPSS. Semarang: Badan Penerbit UniversitasDiponegoro.

Ghozali, Imam \& Fuad.(2005). Struktur Equation Modeling. Semarang: Badan Penerbit Universitas Diponegoro.

Hidayat. (2003). Kontribusi Manajemen Pembiayaan Pendidikan terbadap proses Peningkatan Produktivitas Pendidikan.Thesis. http://digilib.upi.edu/ pasca/diakses 14 Nopember 2008.

Kardoyo. (2005). Pengaruh Kepemimpinan Kepala Sekolah Pembiayaan Pendidikan dan Peran Komite Sekolabterhadap Kinerja sekolabhttp://Available/ etd0216106-123743 diakses 25 Maret 2008.

Helms, Marilyn M. (2006). Encyclopedia of Management. Thomson Gale USA

Hutapea, Parulian \& Thoha, Nurianna. (2008). Kompetensi Plus. Jakarta: PT Gramedia Pustaka Utama. 
Martono, Trisno. (2009). Kepemimpinan Kepala Sekolah, Kinerja Guru, Budaya Organisasi /http://www.uns.ac.id/cp.penelitian.php?actdet\&id $A=256$. diakses 22 Mei 2009.

Mulyani. (2007). Pengarub Kepemimpinan Kepala Sekolah, Motivasi Berprestasi dan Budaya Sekolah terhadap Produktivitas SMP Negeri di Kabupaten Brebes. Thesis Tidak diterbitkan PPS UNNES.

Prosser, Charles A., \& Quigley, Thomas H. (1950). Vocational Education in Democracy. Chicago: American Technical Society.

Robbins, Stephen. (2007). Perilaku Organisasi. Jakarta: PT Macanan Jaya Cemerlang.

Suyanto. (2009). Kepemimpinan Kepala Sekolah di Era Otonomi Pendidikan (http://www.kompas.com/kompas-cetak/0103/23/dikbud/foru09 .html diakses 5 Maret 2009.

Taruno, Tukiman. (2008). Penegakkan Disiplin dan Realitas Sosial. http:// 64.203.71.11/kompas-cetak/0409/14/Dikaktika/1262592.html diakses 19 Juni 2008.

Thomas, Alan J. (1971). The Produtive School, A System Analysis Approach to Educational Administration. NewYork: John wiley \& Son, Inc.

Tilaar. (2003). Manajemen Pendidikan Nasional. Bandung: PT Remaja Rosda Karya.

Usman, Husaini. (2006). Teori,Praktek dan Riset Pendidikan. Jakarta: Bumi Aksara.

Utomo. (2007). Analisis Faktor yang Berpengaruh terhadap Produktivitas Guru SMP Negeri di Kabupaten Brebes. Thesis. Tidak diterbitkan PPS UNNES.

Wiyanti. (2005). Pengaruh Peran Komite Sekolah dan Budaya Organisasi Sekolah terhadap Produktivitas Sekolah SMA Swasta di kota Sema-rang. Thesis. PPS UNNES Semarang.

http:/ / suaramerdeka.Om/v1/index.php/read/news/2010/08/03

/61431/284- Pelajar-Solo-Putus-Sekolah diakses 18 Nopember 2010. 